\title{
Um método prático de racionamento das aves domésticas
}

\author{
(Nota Suplementar)
}

\author{
A. Di Paravicini Torres \\ Seçăo de Avicultura e Cunicultura da Escola Superior \\ de Agricultura "Luiz de Queiroz" \\ Universidade de S. Paulo
}

\section{INDICE}

Métodos da tabua ........................ 324

Método da fórmula $\ldots \ldots \ldots \ldots \ldots \ldots \ldots \ldots \ldots \ldots \ldots \ldots \ldots \ldots$

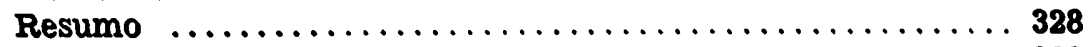

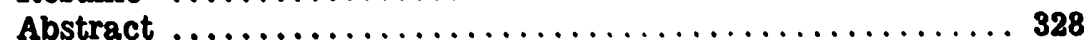


Em outro trabalho (*), publicado nestes "Anais", elaboramos um método prático para composiçăo de fórmulas de raçôes para aves domésticas, acessivel aos práticos com poucos conhecimentos matemáticos e servindo ao mesmo tempo para abreviar a operaçăo, pela rapidez e simplicidade com que pode ser aplicado.

Afim de se conseguir o teor desejado em proteina, aconselhámos, entåo, efetuar tentativas adicionando e subtraindo alimentos segundo sua riqueza nesse principio nutritivo.

Hoje, resolvemos apresentar dois novos métodos, que, ellminando as tentativas, dåo um resultado imediato, muito próximo do desejado.

Ambos são baseados no emprégo do milho e da farinha de carne, para completar as 100 partes desejadas de alimentos, em vista desses dois elementos figurarem quase obrigatoriamente nas raçóes, neste pais.

\section{METODO DA TABUA}

Apresentamos, em anexo, uma tabua que dá a quantidade de proteina fornecida pela combinaçăo de uma dada quantidade de milho (na horizontal) associada a uma dada quantidade de farinha de carne de teor $50-53 \%$ (na vertical) Além do tipo de 50 ou 53\% existente no mercado, a farinha de carne de $50 \%$ pode ser obtida misturando-se partes iguais de $40 \mathrm{com}$ $60 \%$ para aproveitamento da tabua.

Se por hipotese necessitamos 40 quilos de farinha de carne e fubá de milho para completar $10 \%$ de proteina que faltam numa ração, procuramos, no corpo da tabua, 10 ou um número próximo que corresponda a dois números marginais, cuja soma seja os 40 quilos desejadas. Veremos que a 15 de farinha de carne e 25 de milho correspondem 9,8 de proteina, o que satisfaz. 12 de farinha de carne e 28 de milho dro apenas 8,6 e 18 de farinha de carne e 22 de milho, dăo 11,1 - esta combinaçáo excessiva e aquela deficiente.

Vejamos um exemplo para esclarecer. Se estivermos compondo pelo nosso método já descrito uma raçăo e tivermos anotado os seguintes ingredientes:

(*) TORRes, A. Di Paravicini, 1946 - Um Método Prático de Racionamento das Aves Domésticas, in "Anais da E. S. A. L. Q." pp. 313. 


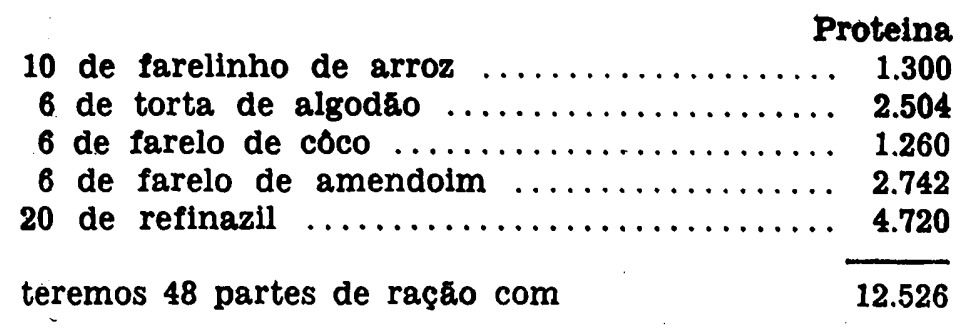

de proteina, para obtermos 100 partes de raçăo com $18,5 \%$ de proteina, precisamos de 52 (100 - 48) partes de milho e farinha de carne, que deem 18,500 - 12,526 $=5,974$ de proteina.

Procurando nas margens da tabua dois números cuja soma seja 52 e que deem perto de $6 \%$ de proteina, achamos como mais indicados

3 de farinha de carne.

48 de fubá de milho

Fica faltando um quilo para totalizar as 100 partes exigidas, mas essa pequena diferença năo tem importancia.

Suponhamos, agora, que pretendemos fazer uma raçăo exclusivamente com milho e farinha de carne, sem outros ingredientes, contendo $18,5 \%$ de proteina. Pela tabela, vemos que tsto é possivel usando

22 quilos de farinha de carne

78 quillos de milho moido,

que dáo 18,3 , resultado muito próximo de $18,5 \%$ e aceitável.

Outro exemplo. Se dispormos apenas de farelinho de arroz para compormos uma raçáo de $18,5 \%$ de proteina (além de milho e farinha de carne), sabendo que a quantidade mais indicada desse ingrediente é de $10 \%$ da raçăo, e se 10 quilos de farelinho de arroz contém 1.300 gramas de proteina, faltam $18,5-1,3=17,2$.

Pela tabua, essa quantidade de proteina pode ser alcançada ajuntando 68 de milho e 22 de farinha de carne que: dão 17,3 de proteina.

\section{MÆTODO DA FORMULA}

- possivel a elaboraçáo de uma fórmula que nas de com exatidáo as quantidades de milho e de farinha de carne necessárlas para completar 100 partes de uma raçåo com um teor desejado de proteina. 
Chamando-se de $\mathbf{M}$ a quantidade de milho a ser adicionada, de. FC a quantidade de farinha de carne, para completar um peso D que falta para 100 quilos de uma raçáo, à qual falta uma porcentagem de proteina $\% \mathbf{P r}$, temos que $\mathbf{M}+\mathbf{F C}=\mathbf{D}$, diferença para atingir 100 de raçăo.

Por outro lado a porcentagem de proteina \% Pr que falta para alcançar o teor desejado de proteina, tem 0 valor

$\% \mathrm{Pr}=0.093 \mathrm{M}+0.500 \mathrm{FC}$, nas quais as constantes 0.093 e 0.500 representam respectivamente a riqueza porcento do $\mathrm{mi}$ tho e da farinha de carne de 50-53\% em proteina bruta.

Temos pois duas equaçóes a duas incognitas
(1) $\mathbf{M}+\mathbf{F C}=\mathrm{D}$
(2) $0.093 \mathrm{M}+0.5 \mathrm{FC}=\% \mathrm{Pr}$

Tirando-se o valor de FC em (1) e substituindo-se em (2),

$$
\mathbf{F C}=\mathrm{D}-\mathrm{M}, \text { portanto }
$$

$$
0.093 \mathrm{M}+0.5(\mathrm{D}-\mathrm{M})=\% \mathrm{Pr}
$$

ou

$$
0.093 \mathrm{M}+0.5 \mathrm{D}-0.5 \mathrm{M}=\% \mathrm{Pr}
$$

ou

$$
0,5 \mathrm{M}-0.093 \mathrm{M}=0.5 \mathrm{D}-\% \mathrm{Pr}
$$

ou

$$
\mathrm{M}(0,5-0.093)=0.5 \mathrm{D}-\% \mathrm{Pr}
$$

$$
\begin{aligned}
\text { Iogo } & \mathbf{M}=-\frac{0,5 \mathrm{D}-\% \mathrm{Pr}}{0.407}=-\frac{\mathrm{D} / 2-\frac{\% \mathrm{Pr}}{0.4}=(\mathrm{D} / 2-\% \mathrm{Pr}) \times 2,5}{\mathrm{C}} & \mathrm{FC}=\mathrm{D}-\mathrm{M}
\end{aligned}
$$

Temos assim, utilizando-se a farinha de carne de 50-53\%, uma fórmula que dá ràpidamente a quantidade de milho, bastando subtrair da diferença $D$, essa quantidade, para se obter a quantidade de farinha de carne a empregar. tabua.

Tomemos os mesmos exemplos utilizados no método da

1.0 - Em dada raçăo faltavam $40 \mathrm{kgs}$. de farinha de carne e fubá para completar $10 \%$ de proteina que faltavam também. Que quantidade desse dois ingredientes usar ?

Pela nossa formula, a quantidade de milho é igual à metade da diferença D (40), menos a porcentagem de proteina que falta, \% $\operatorname{Pr}(10)$, dividido por 0.407 .

Teremos $40 / 2=20-10=10 / 0,407=24.6$ de milho $e$ $40-24,6=15,4$ de farinha de carne. 
2.0 - 48 partes de ração contêm $12.526 \%$ de proteina bruta; para fazer uma ração de $18,5 \%$ de proteina, quanto devemos adicionar de milho e de farinha de carne?

$$
\begin{aligned}
& \operatorname{Pr}=18,5-12,5=6 \quad \mathrm{D}=100-48=52 \\
& \mathrm{M}=\frac{(52 / 2)-6}{0.4}=\frac{26-6}{0.4}=\frac{20}{0.4}=50 \mathrm{kgs} . \text { de milho }
\end{aligned}
$$

$\mathbf{F C}=52-50=2 \mathrm{kgs}$. de farinha de carne.

Evidentemente esta ração levaria uma quantidade extremamente pequena de farinha de carne devido ter-se empregado como base quase exclusivamente alimentos já ricos em proteinas como as tortas de oleaginosas e o refinasil - farelo proteinoso de milho.

3.0 - Em que quantidade o milho e a farinha de carne devem ser reunidos para darem uma ração com $18,5 \%$ de proteina bruta?

$$
\begin{gathered}
\mathrm{M}=\frac{100 / 2-18,5}{0,4}-\frac{50-18,5}{0,4}=\frac{31,5}{0,4}=78,750 \text { de milho } \\
\mathrm{FC}=100-78,750=21,250 \text { de farinha de carne } 50-53 \%
\end{gathered}
$$

Para a farinha de carne de $40 \%$ a fórmula passaria a ser

$$
\mathrm{M}=\frac{0,4 \mathrm{D}-\% \mathrm{Pr}}{0,307} \text { ou } \frac{0,4 \mathrm{D}-\% \mathrm{Pr}}{0,3}
$$

Com menos aproximação, c para a farinha de carne de $60 \%$ seria.

$$
\left.\mathrm{M}=\frac{0,6 \mathrm{D}-\% \mathrm{Pr}}{0,507} \text { ou } 2(0,6 \mathrm{D}-\% \mathrm{Pr}) \text { ou } 1,2 \mathrm{D}-2 \% \mathrm{Pr}\right)
$$

com menor aproximaçăo. 


\section{RTSUMO}

Neste trabalho, o A representa uma tabua e formulas que permitem completar a quantidade de proteina bruta exdgida numa raçăo para aves utilizando como variáveis, a farinha de carne e o milho - que, neste país, entram sempre nas raçoes.

Os metodos, simples e práticos, constituem um suplemento de trabalho já publicado nestes "Anais" sob o mesmo título.

\section{ABSTRACT}

This paper deals with a table and a formula method for determining the quantity of crude protein necessary for a poultry ration, using as variables meat meal and corn, which are the most common foods in this country.

These methods, simple and practical, constitute supplement of a paper published in these "Anais" under the same title. 